THE STILLBIRTH OF CAPITAL 



\section{THE STILLBIRTH OF CAPITAL \\ Enlightenment Writing and Colonial India}

SIRAJ AHMED

Stanford University Press

Stanford, California 
Stanford University Press

Stanford, California

(C) 2012 by the Board of Trustees of the Leland Stanford Junior University.

All rights reserved.

This book has been published with the assistance of the Mount Holyoke College Dean of Faculty Office.

No part of this book may be reproduced or transmitted in any form or by any means, electronic or mechanical, including photocopying and recording, or in any information storage or retrieval system without the prior written permission of Stanford University Press.

Printed in the United States of America on acid-free, archival-quality paper

Library of Congress Cataloging-in-Publication Data

Ahmed, Siraj Dean, author.

The stillbirth of capital : Enlightenment writing and colonial India / Siraj Ahmed. pages $\mathrm{cm}$

Includes bibliographical references and index.

ISBN 978-0-8047-7522-9 (cloth : alk. paper) — ISBN 978-0-8047-7523-6 (pbk. : alk. paper)

1. English literature-18th century-History and criticism. 2. India-In literature. 3. Colonies in literature. 4. Enlightenment. 5. Great Britain-Colonies-Asia-History. 6. India-HistoryBritish occupation, 1765-1947. I. Title.

PR448.I534A36 2012

$820.9^{\prime} 005-\mathrm{dc} 22$

2011012292

Typeset by Bruce Lundquist in 10/15 Minion. 
For Muthu Beevi Fathima and Syed Kader Ahmed 
